\title{
Phytoremediation Potential of Plants Grown on Reclaimed Spoil Lands*
}

\author{
K. J. Bansah and W. K. Addo
}

Bansah, K. J. and Addo, W. K. (2016), "Phytoremediation Potential of Plants Grown on Reclaimed Spoil

Lands", Ghana Mining Journal, Vol. 16, No. 1, pp. 68 - 75.

\begin{abstract}
Post-mining reclamation is aimed at restoring the productive capacity of the disturbed land and ensuring socio-economic and environmental sustainability. Methods that have been employed for the reclamation activity are reported in the literature. This paper studied the utility of certain plant species in Ghana for remediating mine degraded soils. The roots, stalks and leaves of the plant species were analysed for heavy metal accumulation. It was found that Xylopia aethiopica (Hwentia), Pityrogramma calomelanos (Fern), Chromolaena odorata (Acheampong weed), Leucaena leucocephala (Leucaena), and Terminalia superba (Ofram) have accumulated significant concentrations of the heavy metals and are highly suitable for cleaning copper, cadmium, lead, manganese and iron contaminated sites. Food and cash crops, Colocasia esculenta (Cocoyam), Musa sapientum (Banana), and Theobroma cacao (Cocoa) were also observed to have high uptake potential of the heavy metals. Thus, these crops are not recommended on rehabilitated polluted soils until such soils are rid of the contaminants to acceptable levels to mitigate potential concerns by consumers, because local indigenes and the community consume the leaves and tubers of Colocasia esculenta, the beans of Theobroma cacao and the fruits of Musa sapientum.
\end{abstract}

Keywords: Phytoremediation, Bioremediation, Contaminated Soils, Degraded Soils, Heavy Metal

\section{Introduction}

Reclamation of mine degraded lands is expected to ensure environmental sustainability while supporting the livelihoods of the landholders. Mborah et al. (2015) outline various uses to which a reclaimed land could be put. Post-mining landuse should be one that contributes most effectively to the productive capacity and stability of the ecosystem. The post-mining landuse in recent times determines the reclamation planning. Cao (2007) notes that disturbed lands resulting from mining activities still have some potential for economic, recreational and aesthetic use. In developing countries such as Ghana, reclaimed mine degraded sites are typically utilized for economic purposes. Often times, the mining companies reclaim the land in the form that can support subsistence farming and also for the cultivation of cash and food crops such as oil palm plantations, cocoa, oranges and plantain. However, disturbed mining lands can be contaminated with high concentrations of heavy metals that may be absorbed by the crops.

Various methods have been used to decontaminate or amend the soil ecosystem of rehabilitated mine degraded soils to increase the success of reclamation efforts (Haering et al. 2000; Sopper, 1992; Sheoran et al., 2010; Singh et al., 2002; Sutton, 1987; Thames, 1977; Chen, 2000; Cunningham and Bert, 1993).

Phytoremediation, a sustainable and inexpensive remediation strategy which employs plants to remove contaminants from degraded or polluted soils is emerging as a viable alternative to traditional methods of remediating contaminated lands (Khan et al., 2000). Fast growing plants with high metal uptake ability and rapid biomass gain are reported to enhance phytoremediation as a viable strategy for decontaminating contaminated soils. Wei et al. (2004) report the utilization of weed resource in the remediation of soils contaminated with heavy metals. The technique has often involved the utilization of some special plants to clean polluted environment through extraction, volatilization, translocation and stabilization.

The Reclamation Security Agreement signed with the Environmental Protection Agency (EPA) of Ghana, obliges mining companies by regulation to progressively (or after life of mine) revegetate mined-out areas or disturbed lands including tailings dam and spent heap leach piles surfaces. The regulatory requirement also demands from the mines, the establishment of suitable, permanent and diverse vegetative cover capable of supporting landuse options including agriculture and secondary forests development. Restoring productivity potential of disturbed lands to provide such renewable resources requires coherent functioning of soil and plant system. However, community and public perceptions about mining activities and the use of chemicals, coupled with historic issues of cyanide spillages in the mining area undermine reclamation efforts; the quality of food crops produced from revegetated mine sites are often in doubt. 
To assure public health and safety, various species of plants are cultivated on reclaimed mine/disturbed lands at the AngloGold Ashanti Iduapriem mine in the Tarkwa area of the Western Region of Ghana. The plants are expected to be harvested for periodic assessments to estimate their potential for heavy metal accumulation, with the view of using them for potential remediation of contaminated rehabilitated sites. In this study, various plants species that survive on rehabilitated spoil lands were harvested and analyzed for their heavy metal contents. The concentrations of heavy metals accumulated in the roots, stalks and leaves of the plants were determined to establish their phytoremediation potential. Fig. 1 shows the study area.

\subsection{Soil Remediation Techniques}

Soil remediation is necessary when levels of heavy metals are so high that food crops cannot safely be grown in them. The easiest form of remediation is to convert the contaminated land to non-food crops such as flowers and ornamentals. The application of lime to increase soil $\mathrm{pH}$, and thus reducing the uptake of heavy metals by food crops is also practiced.

Chen (2000) reports some of the field and pot experiments carried out in Taiwan to remediate contaminated soils. The following techniques by Lee and Chen (1994), Wang et al. (1994a, 1994b) and Chen and Lee (1997a) are reported:

(i) Chemical stabilization to reduce the solubility of heavy metals by adding nontoxic materials to the soil.

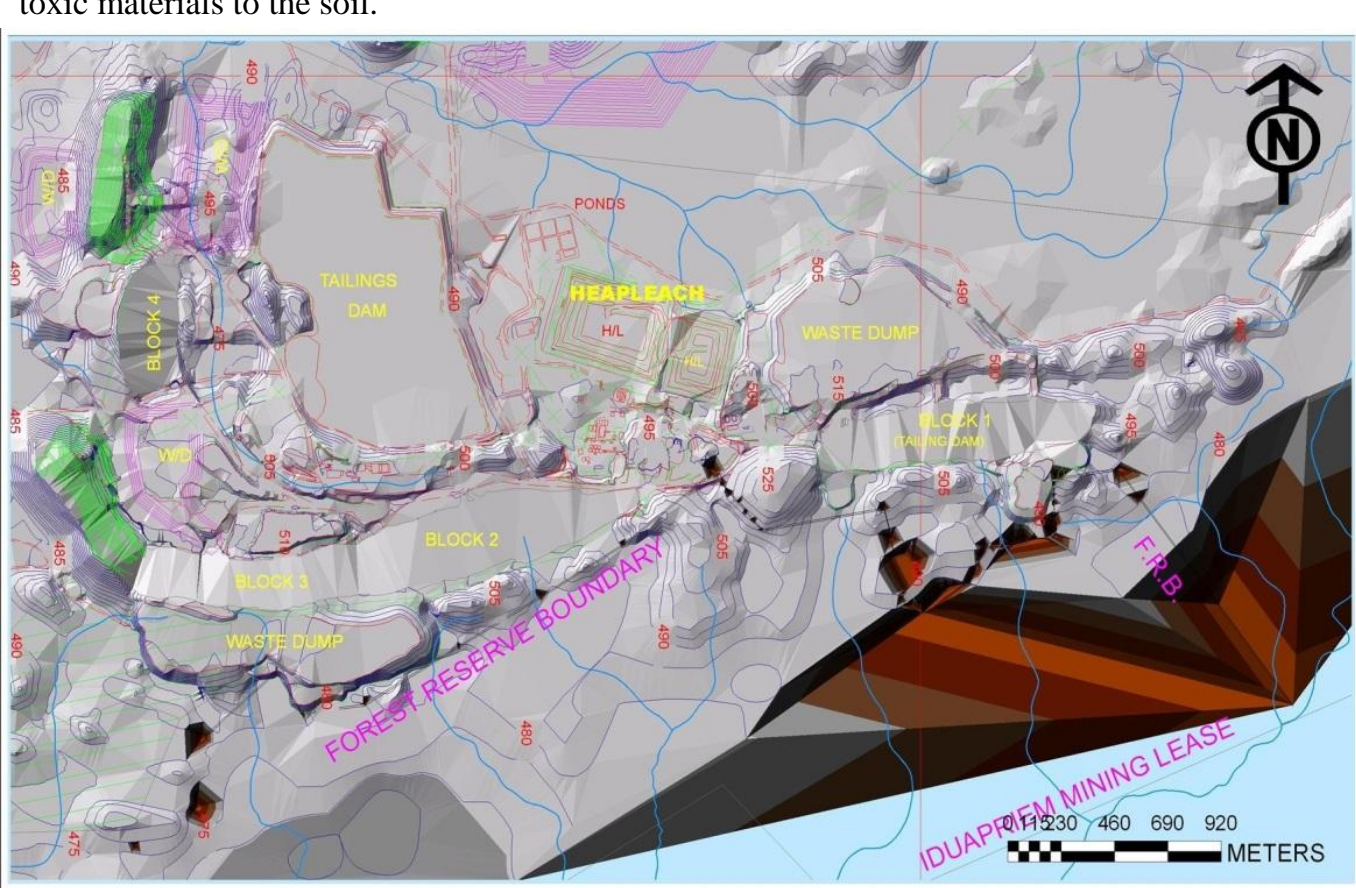

Fig.1 Study Area (Tailings Dam, Heap Leach \& Waste Dump) (ii) Removal of polluted surface soil, and replacing it with clean soil.

(iii) Covering the original polluted soil with clean soil.

(iv) On-site chemical leaching, using some acid agent.

(v) The dilution method of mixing polluted soil with clean soil to dilute the concentration of heavy metals.

(vi) Remediation by plants, using for example suitable tree species.

According to Chen (2000), chemical stabilization seems to be the most cost-effective remediation technique for contaminated sites. However, methods involving the removal of polluted soil, and the addition of clean soil to the surface, or remediation by plants, have also been effective in some cases. The application of dolomite, phosphates or organic matter into polluted soil helps to immobilize heavy metals, so that they cannot be taken up by plants. These materials can reduce the concentration of heavy metals by precipitation, adsorption, or complexation (Chen and Lee, 1997a). The application of calcium carbonate materials can significantly reduce the solubility of heavy metals in contaminated soils (Chen and Lee, 1997b). Many reports also indicate that the application of iron hydroxides or manganese oxides significantly reduces the concentration of soluble cadmium or lead in contaminated soil (Chen and Lee, 1997a). 
Phytoremediation, a bioengineering technique for environmental management uses certain plant species to absorb heavy metals from contaminated soils. Such plant species (known as hyperaccumulator plants) have strong affinity to accumulate the heavy metals in their tissues. Cunningham and Bert (1993) describe phytoremediation as an emerging technology driven by solar energy and employ the use of higher plants to rid contaminated aquatic and terrestrial sites of toxic metals. It is found to be cost effective and environmentally sound compared to chemical remediation technologies.

In a research conducted by the Taiwan Livestock Research Institute, eight plants that grow well in fields polluted with heavy metals were studied to see how much heavy metal they removed from polluted soil, when they were grown from seed in polluted fields in Taiwan. Such plants include fireweed (Crassocephalum crepidioides (Benth) S. Moore), Black nightshade (Solanum nigrum L.), sword fern, Zoysia grass (Zoysia tenuifolia Willd.), rape (Brassica campestris L.), green amaranth (Amaranthus viridus L.), red amaranth (Amaranthus caudatus L.), and edible amaranth (Amaranthus mangostanus L.). The results showed that sword fern, Zoysia grass, rape, green amaranth, red amaranth, and edible amaranth all survived and concentrated a high concentration of cadmium

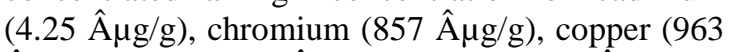
$\hat{A} \mu \mathrm{g} / \mathrm{g})$, nickel (622 ÂAg/g) and zinc (995 Â $\mu \mathrm{g} / \mathrm{g})$.

Phytoremediation technology can be employed in several ways to decontaminate polluted sites (Bondada and Ma, 2003). These include phytoextraction, phytodegradation, rhizofiltration, phytostabilization, and phytovolatilization. Phytoextraction also called phytomining or phytoaccumulation involves planting hyperaccumulators that take up and translocate metal contaminants from soil to the above-ground portions, and then harvested to remove the contaminant from the site. According to Bondada \& Ma (2003), phytodegradation (also called phytotransformation) involves "disintegration of pollutants that may occur within the plant by the metabolic activity or breakdown of the pollutant external to the plant contributed by various organic compounds released into the rhizosphere".

In rhizofiltration, the plants are used primarily to rid contaminants that are in solution (Dushenkov et al., 1995). The plant roots absorb, concentrate, and precipitate metals from contaminated groundwater surrounding the root zone. Phytostabilization is the use of plants to immobilize contaminants in the soil and groundwater through absorption and accumulation by root or precipitation within the rhizosphere (Schnoor, 2002; Conesa et al., 2007).
The process reduces the mobility of the contaminant and prevents migration to groundwater and air, while mitigating the bioavailability for entry into the food chain. In phytovolatilization, the plants take up the pollutants from the soil or water in the transpiration stream and volatilize into the atmosphere in a modified or unmodified form.

\subsection{Rehabilitation at AngloGold Ashanti (Iduapriem) Mine}

Laws and regulations are enacted to ensure that mined-lands are reclaimed properly. However, the goal of reclamation is to ensure a permanently stable landscape that is aesthetically and environmentally compatible with surrounding undisturbed lands. It requires restoration of the mined-out lands to approximate pre-mining topography, spreading of all or most of the original soil material, and reestablishment of the same or similar vegetative cover (Sengupta, 1993).

The following procedure is adopted for tailings dam rehabilitation at AngloGold Ashanti Iduapriem mine:

(i) After tailings deposition and dismantling of pipes and infrastructure, the tailings is allowed to consolidate over 6-9 month period;

(ii) Planting of Bracharia grass over tailings dam surface to suppress dust;

(iii) Digging of $30 \mathrm{~cm}$ deep holes and filling with black soil is carried out;

(iv) Planting of seedlings and cuttings using nitrogen fixing plants;

(v) After establishment of vegetation over three years, food and cash crops are then introduced on trial basis;

(vi) Organic fertilizer in the form of chicken droppings or poultry manure is applied to the crops;

(vii) Agronomic practices such as weeding and pest infestation controls are then adopted;

(viii) Survival rate is computed for both nitrogen fixing plants and food crops;

(ix) Soil samples taken to determine the nutrient status of the soil;

(x) Crop samples sent to laboratory to determine the heavy metal content.

Fig. 2 illustrates reclaimed tailings dam at AngloGold Ashanti Iduapriem mine. 


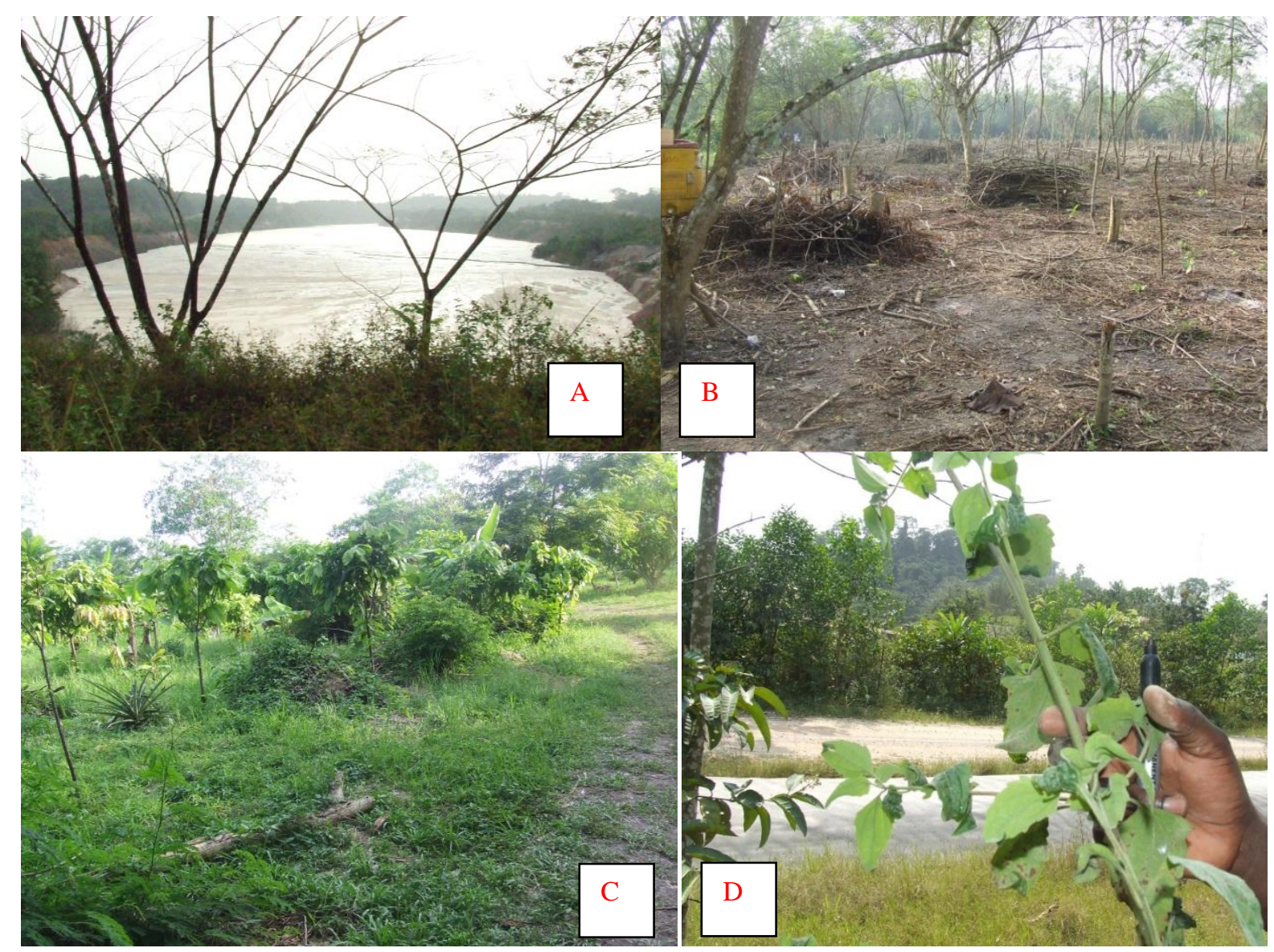

Fig. 2 Reclaimed Tailings Dam: (A) Pre-reclamation Stage, (B) Reclamation Stage, (C) Revegetated Site (at 7 years), and (D) Chromolaena Odorata from the Site

\section{Resources and Methods Used}

The following sections describe the sample collection procedure and the laboratory analysis conducted.

\subsection{Sample Collection}

Eight different plant species, namely: Colocasia esculenta (Cocoyam), Terminalia superba (Ofram), Leucaena leucocephala (Leucaena), Pityrogramma calomelanos (Fern), Xylopia aethiopica (Hwentia), Musa sapientum (Banana), Chromolaena odorata (Acheampong weed) and Theobroma cacao (Cocoa) were collected from various locations of the rehabilitated sites at AngloGold Ashanti (Iduapriem) mine. Five samples of each plant species including roots, stems and leaves were collected from each location. The samples were placed in labeled bags and transported to the Centre for Scientific and Industrial Research (CSIR) laboratory in Kumasi, Ghana for heavy metal analysis. Similarly, soil samples (3-5 replicates) at $0-20 \mathrm{~cm}$ depth from the rhizosphere of each plant species were collected. Fig. 3 shows samples of soil and Pityrogramma calomelanos being prepared for testing in the laboratory.

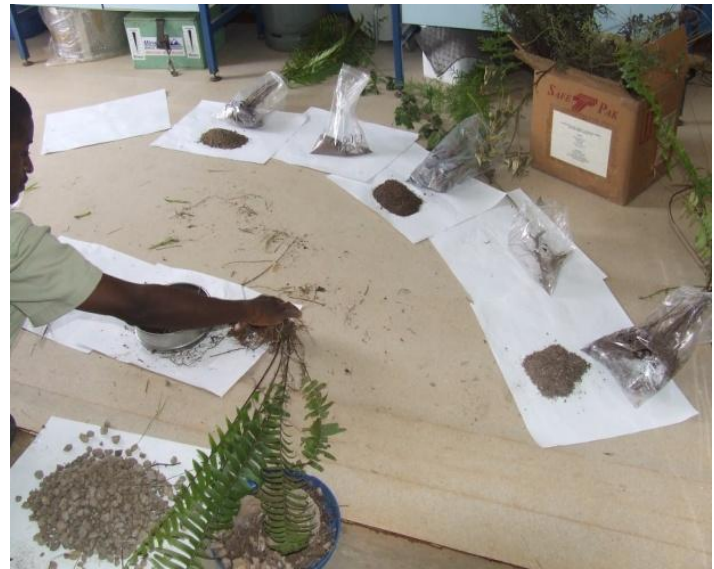

Fig. 3 Soil and Plant Samples under Investigations

\subsection{Laboratory Investigations}

The plant samples were carefully removed from the bags and washed for about three minutes with tap water and de-ionized water to remove any soil or contaminants. The samples were dried at room temperature for two weeks, pulverized and passed through $2 \mathrm{~mm}$ stainless steel sieve. A composite mixture of the soil samples were air dried at room temperature for two weeks, crushed and pulverized to pass through $2 \mathrm{~mm}$ sieve. For each soil sample a 
paste $(1: 1)$ was prepared and the $\mathrm{pH}$ measured using TDA pH meter (HM-16S). The plant and soil samples were digested to enable metal analysis.

The digestion process and analysis were as follows:

(i) One (1) gram of soil sample in a digestion tube was added to $25 \mathrm{ml}$ aliquot of HNO3:H2CLO4 (nitric acid/perchloride) mixture at a ratio of $3: 1$.

(ii) The sample was left in contact with the acid mixture in the digestion tube for 24 hours after which it was heated at $200^{\circ} \mathrm{C}$ until froth ceased.

(iii) The sample mixture was then filtered into a $100 \mathrm{ml}$ capacity volumetric flask and diluted with distilled water.

(iv) Sample of each filtrate was measured for total concentration of $\mathrm{Mn}, \mathrm{Cu}, \mathrm{Zn}, \mathrm{Pb}, \mathrm{Cd}$ and $\mathrm{Fe}$ using an atomic absorption spectrophotometer (Buck Scientific 210 VGP Flame Atomic Absorption Spectrophotometer).

\section{Results and Discussion}

Table 1 presents the results of the heavy metal contents of the soil and plant species after metal analysis at the CSIR. It must be noted that the heavy metal concentration of the soils were not determined prior to the revegetation activities at the study sites. Thus, there is no baseline data on heavy metal concentrations of the soils. However, given the relatively 'normal' $\mathrm{pH}(5.11$ - 7.12), a simple mass balance (Alloway, 1995; Lombi and Gerzabek, 1998) was used to deduce the original heavy metal concentrations of the soils by assuming $10 \%$ losses to account for leaching and volatilization.

It is generally observed that all the plants have high potential of removing heavy metals from contaminated soils. Some of the plant species (Theobroma cacao, Xylopia aethiopica, Pityrogramma calomelanos and Colocasia esculenta) demonstrate high translocation of the heavy metals from the root system to other portions including the stalk and the leaves. For example, it is deduced that the roots of Theobroma cacao accumulated $180.3 \mathrm{mg} / \mathrm{kg}$ of copper from the soil and translocated $136.9 \mathrm{mg} / \mathrm{kg}$ to other parts of the plant (including the stalk, leaves, husk and bean).

Also, Pityrogramma calomelanos, grown on the reclaimed tailings dam absorbed $85.5 \mathrm{mg} / \mathrm{kg}$ of copper through the roots and translocated $22 \mathrm{mg} / \mathrm{kg}$ to the leaves. The roots of Colocasia esculenta absorbed $173.8 \mathrm{mg} / \mathrm{kg}$ of manganese and transferred $53.50 \mathrm{mg} / \mathrm{kg}$ to the leaves. The ability of the root system of a plant to take up high concentrations of heavy metals and sequester into above-ground portions when grown on contaminated soils demonstrates high potential for phytoremediation (Ma et al., 2001). Bondada and Ma (2003) attributed arsenic hyper-accumulation by fern (Chinese Brake) to its extensive root system.

All the plant species demonstrate iron hyperaccumulation. Indeed, the heavy metal content of the plant species is highest for iron. Pityrogramma calomelanos, Musa sapientum, Xylopia aethiopica, and Colocasia esculenta exhibit high potential for bioremediating iron contaminated sites, even though the other plant species (Theobroma cacao, Terminalia superba and Leucaena leucocephala) show considerable uptake of iron. The cadmium and lead uptake by the plants indicate that the plants have highly effective cadmium- or leadscavenging mechanisms. However, it is noted that the stalk of Leucaena leucocephala did not show cadmium accumulation. Since there is no data on cadmium uptake by the root system of Leucaena leucocephala, the authors are unable to determine cadmium bioremediation potential by Leucaena leucocephala in this study.

It is demonstrated that Xylopia aethiopica, Pityrogramma calomelanos, Chromolaena Odorata, Leucaena leucocephala, and Terminalia superba have high phytoremediation potential and can be adopted for remediating copper, cadmium, lead, manganese and iron contaminated sites. Also, Colocasia esculenta, Musa sapientum and Theobroma cacao have shown potential to accumulate large amounts of the heavy metals. Though the heavy metal contents of the food and cash crops (Colocasia esculenta, Musa sapientum and Theobroma cacao) from the reclaimed spoil lands generally compare well with heavy metal concentrations reported for fresh vegetables, cereals and fruits in Saudi Arabia by Ali and AlQahtania (2012), growing these plants on contaminated soils might be of concern to consumers. This is because the leaves and tubers of Colocasia esculenta, the beans of Theobroma cacao and the fruits of Musa sapientum which have shown potential for accumulating heavy metals are commonly eaten by the local people. Based on these findings, these plants are not recommended on reclaimed sites with high levels of heavy metals (such as $\mathrm{Pb}, \mathrm{Cu}, \mathrm{Cd}$ and $\mathrm{Mn}$ ) to mitigate potential heavy metal poisoning. 
Table 1 Heavy Metal Content of Plants and Soil at the Rehabilitated Spoil Lands

\begin{tabular}{|c|c|c|c|c|c|c|c|c|}
\hline \multirow{2}{*}{ Plant Species } & \multirow{2}{*}{ Part } & \multicolumn{5}{|c|}{ Heavy metal concentration $(\mathrm{mg} / \mathrm{kg})$} & \multirow{2}{*}{ Soil pH } & \multirow{2}{*}{ Location } \\
\hline & & $\mathrm{Cu}$ & $\mathrm{Cd}$ & $\mathrm{Pb}$ & $\mathrm{Mn}$ & $\mathrm{Fe}$ & & \\
\hline \multirow{7}{*}{ Theobroma cacao } & Root & 43.40 & 4.10 & 5.74 & 117.2 & 468.00 & \multirow{7}{*}{7.12} & \multirow{7}{*}{ TD } \\
\hline & Stalk & 90.00 & 1.67 & 50.00 & 95.00 & 108.30 & & \\
\hline & Leaves & 13.50 & 3.00 & 7.50 & 241.5 & 73.50 & & \\
\hline & Husk & 12.50 & 1.50 & 3.00 & 64.00 & 63.00 & & \\
\hline & Bean & 20.90 & 2.43 & 7.77 & 16.02 & 22.82 & & \\
\hline & Soil $^{b}$ & 14.00 & 0.36 & 6.23 & 135.50 & $* *$ & & \\
\hline & Soil $^{a}$ & 213.73 & 14.37 & 88.26 & 736.14 & $* *$ & & \\
\hline \multirow{4}{*}{ Colocasia esculenta } & Root & 53.10 & 6.25 & 14.10 & 120.30 & 1127.00 & \multirow{4}{*}{5.73} & \multirow{4}{*}{ TD } \\
\hline & Leaves & 18.00 & 1.00 & 2.00 & 53.50 & 110.50 & & \\
\hline & Soil $^{b}$ & 8.50 & 1.25 & 8.30 & 170.00 & 2426.45 & & \\
\hline & Soil $^{a}$ & 87.56 & 9.35 & 26.84 & 378.18 & 4030.35 & & \\
\hline \multirow{4}{*}{ Terminalia superba } & Root & 157.0 & 16.70 & 70.00 & 30.00 & 406.70 & \multirow{4}{*}{6.64} & \multirow{4}{*}{ TD } \\
\hline & Leaves & 27.40 & 8.06 & 12.90 & 87.10 & 317.70 & & \\
\hline & Soil $^{b}$ & 3.89 & 0.95 & 8.50 & 150.56 & 4001.89 & & \\
\hline & Soil $^{a}$ & 207.12 & 28.28 & 100.54 & 294.43 & 5198.92 & & \\
\hline \multirow{3}{*}{ Leucaena leucocephala } & Stalk & 10.47 & 0.00 & 4.65 & 18.60 & 120.35 & \multirow{3}{*}{5.90} & \multirow{3}{*}{ TD } \\
\hline & Soil $^{b}$ & 10.71 & 1.69 & $* *$ & 130.43 & 989.79 & & \\
\hline & Soil ${ }^{a}$ & 23.30 & 1.86 & $* *$ & 163.93 & 1221.15 & & \\
\hline \multirow{4}{*}{ Xylopia aethiopica } & Root & 52.78 & 0.00 & 15.70 & 27.78 & 538.89 & \multirow{4}{*}{5.11} & \multirow{4}{*}{ TD } \\
\hline & Leaves & 22.92 & 0.00 & 20.80 & 122.92 & 85.420 & & \\
\hline & Soil $^{b}$ & 1.03 & 0.87 & 5.23 & 23.50 & $* *$ & & \\
\hline & Soil ${ }^{a}$ & 26.35 & 0.96 & 28.63 & 161.06 & $* *$ & & \\
\hline \multirow[b]{2}{*}{ Musa sapientum } & Peel & 9.50 & 1.00 & 0.50 & 22.50 & 197.50 & \multirow[b]{2}{*}{5.35} & \multirow[b]{2}{*}{ TD } \\
\hline & Fruit & 11.00 & 3.00 & 7.00 & 9.50 & 19.50 & & \\
\hline \multirow{4}{*}{$\begin{array}{l}\text { Pityrogramma } \\
\text { calomelanos }\end{array}$} & Root & 63.50 & 1.35 & 4.00 & 78.77 & 1789.96 & & \\
\hline & Leaves & 22.00 & 32.59 & 11.24 & 230.78 & 0.06 & & \\
\hline & Soil $^{b}$ & 23.50 & 2.31 & 8.15 & 19.58 & 23500.08 & 0.22 & TD \\
\hline & Soil $^{a}$ & 119.90 & 39.88 & 25.73 & 362.04 & 27819.11 & & \\
\hline & Root & 66.98 & 1.89 & 4.72 & 90.57 & 2141.50 & & \\
\hline Pityrogramma & Leaves & 25.90 & 34.30 & 12.10 & 236.14 & 101.20 & & \\
\hline calomelanos & Soil $^{b}$ & 26.47 & 2.45 & 8.82 & 30.39 & 23539.20 & 5.80 & WD \\
\hline & Soil $^{a}$ & 131.29 & 42.50 & 28.20 & 392.81 & 28360.09 & & \\
\hline & Root & 78.30 & 3.77 & 9.43 & 32.08 & 3113.20 & & \\
\hline Pityrogramma & Stem & 11.81 & 0.00 & 16.00 & 15.97 & 127.08 & & \\
\hline calomelanos & Soil $^{b}$ & 18.67 & 1.82 & 6.625 & 148.73 & 1515.91 & 5.50 & LP \\
\hline & Soil ${ }^{a}$ & 119.66 & 6.149 & 35.26 & 216.46 & 5231.80 & & \\
\hline & Root & 78.30 & 3.77 & 9.43 & 32.08 & 3113.20 & & \\
\hline & Leaves & 8.00 & 2.00 & 15.50 & 12.50 & 122.00 & 627 & \\
\hline Chromolaena Udorata & Soil $^{b}$ & 12.69 & 2.05 & 6.52 & 159.31 & 1533.64 & 0.21 & $\mathrm{LP}$ \\
\hline & Soil ${ }^{a}$ & 108.89 & 8.60 & 34.60 & 224.28 & 5245.72 & & \\
\hline
\end{tabular}

Note: TD - Rehabilitated Tailings Dam, LP - Rehabilitated Leach Pad, WD - Rehabilitated Waste Dump, Soil ${ }^{a}$ Pre-vegetation, Soil ${ }^{b}$-Post-harvesting, **No Available Data 


\section{Conclusions and Recommendation}

This paper reports the utility of certain plant species in Ghana for bioremediating metalcontaminated sites. In the study, eight plant species harvested from rehabilitated degraded sites at AngloGold Ashanti Iduapriem Limited in Ghana show heavy metal accumulation in their roots and above-ground portions. It is deduced from the results that the plant species, Xylopia aethiopica, Pityrogramma calomelanos, Chromolaena Odorata, Leucaena leucocephala, and Terminalia superba are highly suitable for cleaning copper, cadmium, lead, manganese and iron contaminated sites. Food and cash crops, namely, Colocasia esculenta, Musa sapientum, and Theobroma cacao also demonstrate heavy metal uptake potential, and are therefore not recommended on rehabilitated mine degraded soils, unless such soils contain acceptable levels of heavy metals. This would mitigate potential health concerns by consumers.

\section{References}

Ali, M. H., \& Al-Qahtani, K. M. (2012), "Assessment of some Heavy Metals in Vegetables, Cereals and Fruits in Saudi Arabian Markets, The Egyptian Journal of Aquatic Research, 38(1), pp. 31-37.

Alloway, J. B. (1995), Heavy Metals in Soils, Blackie Academic and Professional, London, UK, 2nd Edition.

Bondada, B. R. And Ma, L. Q. (2003), Tolerance of Heavy Metals in Vascular Plants: Arsenic Hyperaccumulation by Chinese Brake Fern (Pterzs Vzttata L.), Pteridology in The New Millennium, S. Chandra \& M. Srivastava (eds.), Kluwer Academic Publishers, Netherlands, pp. 397-420.

Chen, Z. S. (2000), "Relationship between Heavy Metal Concentrations in Soils of Taiwan and Uptake by Crops", FFTC Publication Database, $10 \mathrm{pp}$.

Chen, Z. S. and Lee D. Y. (1997a), "Evaluation of Remediation Techniques on Two Cadmium Polluted Soils in Taiwan". In: Remediation of Soils Contaminated with Metals, A. Iskandar, and D. C. Adriano (Eds.), Science Reviews, Northwood, UK,. pp. 209-223.

Chen, Z. S., and Lee, D. Y. (1997b), "Soil Quality Management in Taiwan Rural Soils after Long-Term Application of Organic Composts", In: Proceedings of International Conference on Soil Quality Management and Agro-Ecosystem Health for East and Southeast Asia, Korean Society of Soil Science and Fertilizer, Cheju Island, Korea, pp. 137-147.

Conesa, H. M., Faz, Á., \& Arnaldos, R. (2007), "Initial Studies for the Phytostabilization of a
Mine Tailing from the Cartagena-La Union Mining District (SE Spain)", Chemosphere, Vol. 66, Issue 1, pp. 38-44.

Dushenkov, V., Kumar, P. N., Motto, H., \& Raskin, I. (1995), "Rhizofiltration: The Use of Plants to remove Heavy Metals from Aqueous Streams", Environmental Science \& Technology, Vol. 29, Issue 5, pp. 1239-1245.

Haering, K. C., Daniels, W. L., Feagley, S. E. (2000), "Reclaiming Mined Lands with Biosolids, Manures, and Papermill Sludges", In: Reclamation of Drastically Disturbed Lands, Agronomy Monograph No. 41, American Society of Agronomy, Crop Science Society of America, Soil Science Society of America, Madison, WI, pp. 615-644.

Khan, A. G., Kuek, C., Chaudhry, T. M., Khoo, C. S., \& Hayes, W. J. (2000), "Role of Plants, Mycorrhizae and Phytochelators in Heavy Metal Contaminated Land Remediation", Chemosphere, Vol. 41, Issue 1, pp. 197-207.

Lee, D. Y. and Chen, Z. S. (1994), "Plants for Cadmium Polluted Soils in Northern Taiwan", In: Biogeochemistry of Trace Elements, D.C. Adriano, Z.S. Chen, and S.S. Yang (Eds.), Special Issue of Jour. Environ., Geochem and Health 16: pp. 161-170.

Lombi, E. and Gerzabek, H. M. (1998), "Determination of mobile heavy metal fraction in soil: results of a pot experiment with sewage sludge," Communications in Soil Science and Plant Analysis, Vol. 29, No. 17-18, pp. 25452556.

Mborah, C., Bansah, K. J., \& Boateng, M. K. (2015), "Evaluating Alternate Post-Mining Land-Uses: A Review", Environment and Pollution, Vol. 5, Issue 1, pp. 14-22.

Thames, J. L. (1977), Reclamation and Use of Disturbed Land in the Southwest, University of Arizona Press, 362 pp.

Schnoor, J. L. (2000), "Phytostabilization of Metals using Hybrid Poplar Trees, Phytoremediation of Toxic Metals: Using Plants to Clean-up the Environment", New York, John Wiley \& Sons, Inc, pp. 133-150.

Sengupta, M. (1993), Environmental Impacts of Mining, Monitoring Restoration and Control, Lewis Publishers, New York, pp. 103-119.

Sheoran, V., Sheoran, A. S., \& Poonia, P. (2010), "Soil Reclamation of Abandoned Mine Land by Revegetation: A Review", International Journal of Soil, Sediment and Water, Vol. 3, Issue 2, p. 13.

Singh, A. N., Raghubanshi, A. S., \& Singh, J. S. (2002), "Plantations as a Tool for Mine Spoil Restoration”, Current Science, Vol. 82, Issue 12, pp.1436-1441.

Sopper, W. E. (1992), "Reclamation of Mine Land using Municipal Sludge", In Soil Restoration, Springer New York, pp. 351-431. 
Sutton, P. \& Dick, W. A. (1987), "Reclamation of Acidic Mined Lands in Humid Areas", Adv. Agron, 41, pp. 377-405.

Wang, Y. P., Chen, Z. S, Li, K. C., Lin, H. T., Huang, Y. M., Huang, C. L. and Liu, C. L. (1994a), "Assessment of Soil Pollution and Soil Remediation Techniques Tested in the Polluted Soils of Taiwan", Project Report of EPA-ROC (Grant No. EPA-83-H105-09-04), Taipei, Taiwan, ROC Wang, Y. P., Chen, Z. S., Liu, W. C., Wu, T. H., Chaou, C. C. Li, G. C., and Wang, T. T. (1994b), "Criteria of Soil Quality- Establishment of Heavy Metal Contents in Different Categories (Final Report of Four- Year Project)", Project Reports of EPA/ROC (Grant No. EPA-83-E3H1-09-02), $54 \mathrm{pp}$.

Wei, S., Zhou, Q., \& Liu, R. (2004), "Utilization of Weed Resource in the Remediation of Soils Contaminated by Heavy Metals", Journal of Natural Resources, Vol. 20, Issue 3, pp. 432440.

\section{Authors}

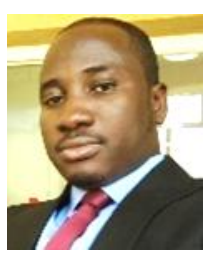

Kenneth J. Bansah is a Graduate Research Assistant and $\mathrm{PhD}$ Candidate at Missouri University of Science and Technology, Missouri, USA. He holds MPhil Degree in Mining Engineering from the University of Mines and Technology, Ghana and BSc. in Mining Engineering from the Kwame Nkrumah University of Science and Technology, Ghana. Since July 2010, Kenneth has been the Director and Chief Consultant of Safety \& Environmental Research Consultancy Limited providing consulting services in environmental and safety issues. His current research areas include blast optimization, artisanal and small scale mining, environmental and engineering applications of geophysics, occupational health and hygiene, safety and environmental management issues. He is a member of SME, CIM, SEG, NSBE, EAGE and AEG.

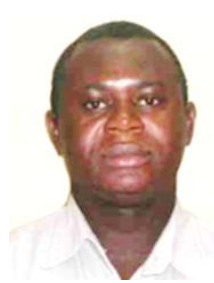

William Addo holds MPhil degree in Mineral Engineering from UMaT, Ghana, Diploma in General Management Practice from the University of Cape Town, South Africa, BSc in Natural Resources Management from Kwame Nkrumah University of Science and Technology, Ghana, and HSE Manager Certificate of Competence from the Inspectorate Division of Minerals Commission of Ghana. In 2009, he was awarded a Diploma in Leadership and Management by the Ghana Institute of Management and Public Administration, Ghana. William obtained Advanced Certificate in Environmental Management from Lulea University of Technology, Sweden in 2003. He has over fifteen years working experience as Environmental Practitioner and currently the Environmental Manager at AngloGold Ashanti Iduapriem Mine. 